\title{
Not just justice: inquiry into missing and murdered Aboriginal women needs public health input from the start
}

\author{
Kirsten Patrick MB BCh DA
}

$\longrightarrow$ n Dec. 8, 2015, the Government of Canada announced its plan for a national inquiry into murdered and missing indigenous women and girls, in response to a specific call to action from the Truth and Reconciliation Commission. ${ }^{1}$ On Jan. 5, 2016, a pre-inquiry online survey was launched to "allow ... [stakeholders an] opportunity to provide input into who should conduct the inquiry, ... who should be heard as part of the inquiry process, and what issues should be considered." 2 We urge the federal government to be cognizant of the substantial knowledge, skill and advocacy of those who work in public health when deciding who should be consulted as part of this important inquiry.

A recent report from the Royal Canadian Mounted Police ${ }^{3}$ confirmed that rates of missing person reports and homicide are disproportionately higher among Aboriginal women and girls than in the non-Aboriginal female population. As rates of female homicide have declined in Canada overall, the rate among Aboriginal women remains unchanged from year to year. This is troubling, and the need to seek testimony from survivors, family members, loved ones of victims and law enforcement agencies in the inquiry is clear. However, we should avoid diagnosing this problem merely as a failure of law enforcement. Murders represent the tip of an iceberg of problems related to endemic violence in communities. Many Aboriginal women and girls, and indeed men and boys, live each day under the threat of interpersonal violence and its myriad consequences.

Initial statements from the three federal ministers tasked with leading the forthcoming inquiry — the ministers of Indigenous and Northern Affairs, Justice and Status of Women suggest that its purpose is to achieve justice, to renew trust between indigenous communities and the Canadian government and law enforcement bodies, and to start a process of healing. The inquiry surely must also endeavour to lay the groundwork for a clear plan to address the broader problem of interpersonal violence, which, in turn, is rooted in several key determinants. Addressing interpersonal violence is not merely an issue of justice; it is also a public health concern.

Factors associated with both the experience and perpetration of interpersonal violence are manifold. They include but are not limited to mental health issues, drug and alcohol misuse, unemployment, social isolation, low income and a history of experiencing disrupted parenting and physical discipline as a child. The Truth and Reconciliation Commission's report has highlighted that many of these factors are widespread in the Aboriginal populations of Canada. ${ }^{4}$ Many of the same factors contribute to disparities between Aboriginal and non-Aboriginal peoples in areas such as education, socioeconomic circum- stances and justice. There is also substantial overlap with identified determinants of poor health in Aboriginal communities both in Canada and elsewhere., ${ }^{5,6}$ These are the factors associated with higher rates of youth suicide, adverse birth outcomes and tuberculosis, and poorer child health. It's clear that a common web - woven of a legacy of colonization and cultural genocide, and a cumulative history of societal neglect, discrimination and injustice - underlies both endemic interpersonal violence and health disparities in Canada's indigenous populations. There is no conversation to be had about one without a conversation about the other — if the aim is healing — because the root causes are the same.

The World Health Organization (WHO) is currently engaged in developing a global plan of action to strengthen the role of health systems in addressing interpersonal violence, particularly that involving women and girls. ${ }^{7} \mathrm{~A}$ draft report by the WHO acknowledges interpersonal violence as a strongly health-related issue that nevertheless requires a multisectoral response tailored to the specific context. Evidence from Aboriginal community models in Canada gives hope for healing. A recent report from the Canadian Council on Social Determinants of Health highlighted important strides that some Aboriginal communities have made to address the root causes of, and to mitigate, inequities through efforts to restore the people's connection with indigenous culture. ${ }^{8}$ Increasing community control over social, political and physical environments has been linked to improvements in health and health determinants.

The public health sector in many parts of Canada has embraced the need for strong community involvement in restoring Aboriginal people to the health that is their right. In many community-led projects over the past few decades, the health care sector has worked with others to address common proximal and distal determinants of disparities. We are presented with not just an opportunity for renewing trust between indigenous communities and the Government of Canada but also for extending the roles of public health and the health care sector in the facilitation of trust and healing. There is much that the health sector can contribute to the forthcoming inquiry. Health Canada should be involved from the start to ensure that public health is properly represented.

\section{References}

1. Truth and Reconciliation Commission of Canada: calls to action. Winnipeg: Truth and Reconciliation Commission of Canada; 2012. Available: www.trc.ca/websites/ trcinstitution/File/2015/Findings/Calls_to_Action_English2.pdf (accessed 2016 Jan. 26).

2. On-line survey: National inquiry into missing and murdered indigenous women and girls. Ottawa: Government of Canada; [modified 2015]. Available: www.aadnc-aandc. gc.ca/eng/1448637991710/1448638013197 (accessed 2016 Jan. 26). 
3. Missing and murdered Aboriginal women: 2015 update to the national operational overview. Ottawa: Royal Canadian Mounted Police; 2015. Available: www.rcmp-grc. gc.ca/pubs/abo-aut/mmaw-fada-eng.pdf (accessed 2016 Jan. 26).

4. Honouring the truth, reconciling for the future: summary of the final report of the Truth and Reconciliation Commission of Canada. Winnipeg: Truth and Reconciliation Commission of Canada; 2015. Available: www.trc.ca/websites/trcinstitution/ File/2015/Honouring_the_Truth_Reconciling_for_the_Future_July_23_2015.pdf (accessed 2016 Jan. 26).

5. Reading CL, Wien F. Health inequalities and social determinants of Aboriginal peoples' health. Prince George (BC): National Collaborating Centre for Aboriginal Health; 2009. Available: http://ahrnets.ca/files/2011/02/NCCAH-Loppie-Wien_Report. pdf (accessed 2016 Jan. 26).

6. Gracey M, King M. Indigenous health part 1: determinants and disease patterns. Lancet 2009;374:65-75.

7. Strengthening the role of the health system in addressing violence, in particular against women and girls, and against children. The Sixty-seventh World Health Assembly. Geneva: World Health Organization; 2014. Available: http://apps.who.int/gb/ebwha/ pdf_files/WHA67/A67_R15-en.pdf (accessed 2016 Jan. 26).

8. Roots of resilience: overcoming inequities in Aboriginal communities. Canadian Council on Social Determinants of Health; 2013. Available: http://ccsdh.ca/images/ uploads/Roots_of_Resilience.pdf (accessed 2016 Jan. 26).

Competing interests: See www.cmaj.ca/site/misc/cmaj_staff.xhtml

Affiliation: Deputy Editor, CMAJ

Correspondence to: CMAJ editor, pubs@cmaj.ca

CMAJ 2016. DOI:10.1503/cmaj.160117 